\title{
The Dynamic Relationship between Ownership Structure and Corporate Performance: Evidence from the Vietnamese Food Industry
}

Submitted 10/02/20, $1^{\text {st }}$ revision 15/03/20, $2^{\text {nd }}$ revision 16/04//20, accepted 30/05/20

\section{Le Duc Toan ${ }^{1}$, Vo Hoang Diem Trinh ${ }^{2}$, Phan Nguyen Bao Quynh ${ }^{3}$, Phan Tran Minh Hung ${ }^{4}$, Pham Thi Ngoc Chau ${ }^{5}$}

\begin{abstract}
:
Purpose: Our analysis provides empirical evidence on the dynamic relationship between ownership structure and corporate performance in the context of Vietnam.

Approach/Methodology/Design: Our findings are drawn from the comprehensive data set of stocks listed on both the Hochiminh Stock Exchange and Hanoi Stock Exchange in the food industry from 2007 to 2018.

Findings: The results indicate that both managerial shareholdings and ownership concentration negatively drive corporate performance. We further find that corporate performance is also a positive function of both managerial shareholdings and ownership concentration.

Practical Implications: The results support the entrenchment hypothesis that the divergence of ownership and control helps managers accumulate substantial private benefits without actually bearing the costs. Block-holders also accumulate private benefits of control through pyramid business structures and cross-holdings across different firms. Therefore, both block-holders and managers are motivated to indulge in non-value maximizing behavior, deteriorating corporate performance.

Originality: The entrenchment hypothesis does only exist at a low level of ownership. At the high level of ownership, the entrenchment hypothesis is positioned by the incentive hypothesis. Accordingly, their self-interest behaviors are more likely to be detected and legally riskier. They are motivated to indulge in value-maximizing behaviors and synchronize the interests of shareholders and managers.
\end{abstract}

Keywords: Vietnamese food listed firms, ownership structure managerial shareholdings, block ownership, corporate performance, dynamic model.

JEL Classification: G32, L25, O16.

Paper Type: Research study.

\footnotetext{
${ }^{1}$ Duy Tan University, Vietnam, leductoan2002@gmail.com;

${ }^{2}$ University of Economics-The University of Danang, Vietnam, trinhvhd@due.edu.vn;

${ }^{3}$ Corresponding author, Quang Trung University,Vietnam,pnbquynh@qtu.edu.vn;

${ }^{4}$ University of Economics-The University of Danang, Vietnam;

phantranminhhung@gmail.com;

${ }^{5}$ FPT School of Business \& Technology,Vietnam,kh.chauptn@fsb.edu.vn;
} 


\section{Introduction}

The seminal work of Meckling and Jensen (1976) and Jensen (1986) related to the conflict of interest between managers and shareholders is considered as the initial basis for the establishment of the modern theoretical framework that is likely to explain most issues of corporate governance. Thus, agency theory has received considerable attention. The conventional literature on ownership structure indicates that the notable agency theory drives the relationship between ownership structure and corporate performance.

A separate but growing body of the literature has shed light on some important effects of ownership structure on firm performance in well-developed markets such as Japan (Gedajlovic and Shapiro, 2002), France (Margaritis and Psillaki, 2010), and European countries (Thomsen and Pedersen, 2000) where ownership structure is highly dispersed. This relationship has also been considered in emerging markets such as Thailand (Kim et al., 2004), Malaysia (Haniffa and Hudaib, 2006). In Vietnam, Hoang et al. (2017), Phung and Mishra (2016), Vu et al. (2018), and Tran and Le (2020) are closest in spirit to our study. However, Phung and Mishra (2016) and Vu et al. (2018) do not examine the effect of both block ownership and managerial ownership on corporate performance. Whereas, Hoang et al. (2017) provide empirical evidence on the linear relationship between managerial ownership and firm performance in the non-linear specification rather than the merely linear specification. Additionally, this analysis only tends to Vietnamese manufacturing listed firms. Tran and Le (2020) consider block ownership for the entire market but not managerial ownership.

Government policies drive the Vietnamese food industry since the food industry is intimately related to food security. Therefore, the effect of these policies on the food industry is stronger than that of other industries. Besides, the food listed firms are characterized by a highly concentrated ownership structure, an underdeveloped, weak national governance system, information asymmetry, and weak disclosures in policies to protect the right of minority shareholders (Nguyen et al., 2015; Phung and Mishra, 2016; Huynh et al., 2020; Tran and Le, 2020).

Vietnam is a less developed country; the demand for food is higher than that for other items. Therefore, to adapt to the demand for food, the food industry has been prioritized to develop. Consequently, since the "Doi Moi" policy, the Vietnamese food industry has developed rapidly. Vietnam has long been recognized as the second-largest exporter in rice and the top exporter in coffee. Therefore, Vietnamese food firms obtained more profit from export. Vietnamese listed firms' governance structure has dramatically changed to suit some recent reforms in corporate governance practices. Although conducted in different markets, the shortage of empirical supports on the nexus between ownership structure and corporate performance in the Vietnamese food industry motivates 
us to revisit whether ownership structure liquidity plays an important role in the mitigation of conflicts between managers and shareholders for Vietnamese food listed firms. Therefore, our contribution is twofold. Our study's biggest novelty lies in the use of the Vietnamese database of listed firms to provide again the empirical support for the significant role played by ownership structure in determining corporate performance in an emerging market. Vietnam was chosen so that theories could be tested and empirical evidence secured to allow for future research possibilities. The existing empirical evidence on the relationship between ownership structure and corporate performance in developing markets is not rich in developed countries. Different socio-economic and political structures in emerging countries could induce heterogeneity in the linkage between ownership structure and corporate performance (Fan et al., 2011). Therefore, this paper provides empirical evidence to better view the relationship between ownership structure and corporate performance in a developing country like Vietnam. The second novel contribution is that we take advantage of the Vietnamese food market's characteristics to investigate the relationship between ownership structure and corporate performance since the differences in the linkage between managerial ownership and firm performance seem to be attributable to discrepancies among industries (Cui and Mak, 2002). Thus, the special dimensions of the food industry can induce differences in the form of linkage between ownership structure and corporate performance, but this would require investigation to confirm hence this and future research.

\section{Literature Review and Hypothesis Development}

The link between ownership structure and corporate performance could be explained by agency theory (Jensen and Meckling, 1976). However, the theoretical framework to explain the relationship between managerial ownership and corporate performance is mixed.

The incentive hypothesis posits that managerial ownership may be attributable to the mitigation of conflicts between managers and shareholders since managerial shareholdings, known as an internal control mechanism, help mitigate information asymmetry between managers and shareholders (Crutchley and Hansen, 1989). The form of managerial ownership is expected to offer managers incentives to reduce agency costs because managers are also co-owner, and they will not accumulate substantial private benefits without actually bearing the costs. Thus, managers are not motivated to indulge in non-value maximizing behaviors, deteriorating corporate performance. Therefore, the increase of managerial shareholdings helps managers willingly forgo managerial myopia and implement policies, synchronizing managers' and shareholders' interests rather than their own self-interests.

The entrenchment hypothesis (Morck et al., 1988) suggests that managers holding a large fraction of the shares above a certain threshold deteriorate 
corporate performance since shareholders cannot discipline managers. Thus, managers take advantage of available resources to pursue their own self-interests instead of shareholders. In other words, the higher the fraction of managerial shareholdings, the higher the motivation for the management to entrench themselves since the more difficult it is for outsiders to control the management. Therefore, the decrease in corporate performance is attributable to managers' self-interests that eventually do not align with the interests of shareholders.

The mixed theoretical predictions for the relationship between ownership structure and corporate performance are the incentive and entrenchment hypotheses. The incentive hypothesis posits that block ownership is known as an influential monitoring mechanism to mitigate the conflicts of interest between managers and shareholders since block-holders with enough voting control are more motivated to acquire more private information and monitor better managers to facilitate takeover efforts or even oust managers who fail to maximize their wealth through a proxy fight or a takeover (Shivdasani, 1993; Shleifer and Vishny, 1986; 1997). When managers have other goals instead of maximizing shareholders' value, they are replaced by block-holders to restructure their firms following the reduction in corporate performance (Kaplan and Minton, 1994; Kang and Shivdasani, 1995). In short, the theoretical framework indicates a significantly positive influence of block ownership on corporate performance. In the meanwhile, the entrenchment effect hypothesis point outs that block-holders cause a negative entrenchment effect on corporate performance since they accumulate private benefits of control through pyramid business structures and cross-holdings across different firms (Claessens et al., 2000). Therefore, ownership concentration seems to be attributable to the conflicts of interest between controlling shareholders and minority shareholders (Filatotchev et al., 2013).

The non-monotonic association between ownership structure changes and subsequent corporate performance is conditional on the incentive and entrenchment hypothesis. Accordingly, the inverted U-shaped (U-shaped) nonlinear relationship exists if block-holder (managerial) ownership positively (negatively) related to corporate performance appears in the first place at low (high) levels of block-holder (managerial) ownership since the incentive (entrenchment) effect can be dominant to the entrenchment (incentive) hypothesis and block-holder (managerial) ownership negatively (positively) related to corporate performance exists in the second place at high (low) levels of block-holder (managerial) ownership since the entrenchment (incentive) effect might be more important.

A separate but growing body of the literature has highlighted the mixed empirical evidence on the nexus between ownership structure and corporate performance. Earle et al. (2005), Grosfeld and Hashi (2007) reveal no significant influence of block ownership on corporate performance in the context of the Hungarian and 
Polish market, respectively. Balsmeier and Czarnitzki (2017) document no significant linear relationship between block ownership and corporate performance in several European countries. Haniffa and Hudaib (2006) find no linkage between changes in managerial shareholdings and subsequent market performance in the Malaysian market. In Vietnam, Hoang et al. (2017), Tran and Le (2020) find no statistical significance of a linear relationship between block ownership and corporate performance.

Kim et al. (2004) tend to newly listed Thai firms to emphasize the importance of managerial shareholdings in emerging markets and indicate the positive effect of managerial shareholdings on corporate performance. In a similar vein, Sheu and Yang (2005) tell a similar story when taking Taiwanese firms in the electronic industry into account. Li et al. (2007) reach the same conclusion for Chinese State-owned firms. Moreover, in China, Liu et al. (2012) indicate the positive impact of managerial shareholdings on firm performance for the entire market. Hoang et al. (2017) tend to Vietnamese manufacturing listed firms to conclude the positive impact of managerial shareholdings on firm performance. Although the empirical evidence on the negative relationship between managerial shareholdings and subsequent corporate performance exists, the negative relationship is not rich compared to the positive relationship. For example, a negative association between managerial ownership and firm performance is well documented in the developed markets such as The USA (Cui and Mak, 2002), Germany (Irina and Nadezhda, 2009). In the developing countries, Mandac1 and Gumus (2010) indicate the negative relationship between managerial shareholdings and subsequent corporate performance in the Turkish market.Haniffa and Hudaib (2006) look solely at Malaysian listed firms to reach the same conclusion.

Cho and Kim (2007) and Kapopoulos and Lazaretou (2007) suggest that the more concentrated ownership structure, the higher the corporate performance in Korean and Greek, respectively. Nguyen et al. (2015) reveal a significantly positive relationship between ownership concentration and corporate performance among Vietnamese and Singaporean firms. The negative relationship between ownership concentration changes and subsequent corporate performance is well documented in Chile (Lefort and Urzúa, 2008) and France (Ducassy and Montandrau, 2015).

Empirically, the non-monotonic relationship between ownership structure and corporate performance has been received considerable attention. An inverted Ushaped relationship between managerial ownership and corporate performance is well documented for German SMEs with a maximum point of $40 \%$ (Mueller and Spitz-Oener, 2006). Liu et al. (2012) indicate a hump-shaped curve for the relationship between managerial ownership and firm performance, with the turning point at about $19.86 \%$ for Chinese listed firms. Chen and $\mathrm{Yu}$ (2012) find that the maximum level that the managerial ownership-performance relationship 
turns from positive to negative is $39.09 \%$ among Taiwanese firms. Khan et al. (2014) reveal that at $22.4 \%$ of managerial ownership level, the relationship consistent with incentive alignment exists in the Australian market. Cui and Mak (2002) look at managerial shareholdings and reveal the nonlinear relationship between managerial ownership and firm performance with a U-shaped curve for high R\&D firms in the USA. In Vietnam, Hoang et al. (2017) reveal the square of managerial shareholdings to be significantly and negatively associated with the market corporate performance measure in the cubic specification.

Non-monotonic relationships between block ownership and corporate performance are also found, for example, an inverted U-shaped pattern in Central and Eastern Europe with the turning point at approximately $47 \%$ (Balsmeier and Czarnitzki, 2017). Cho and Kim (2007) reveal a bell-shaped relationship between a large shareholder ownership rate and profitability with the inflection point at 50.1\%. Liu et al. (2012) document that the maximum level that the block ownership-performance relationship turns from negative to positive is $57 \%$. In Vietnam, both Hoang et al. (2017) and Tran and Le (2020) find that corporate performance is not a quadratic function of block ownership. In the light of the existing theoretical and empirical evidence, the following testable hypotheses are proposed:

Hypothesis 1 (H1a): Managerial ownership is positively related to corporate performance.

Hypothesis 1 (H1b): Managerial ownership is negatively related to corporate performance.

Hypothesis 2 (H2a): Block ownership is positively related to corporate performance.

Hypothesis 2 (H2b): Block ownership is negatively related to corporate performance.

Hypothesis 3 (H3a): Managerial ownership and corporate performance have a non-linear relationship with a $U$-shaped curve.

Hypothesis 3 (H3b): Managerial ownership and corporate performance have a non-linear relationship with an inverted $U$-shaped curve.

Hypothesis 4 (H4a): Block ownership and corporate performance have a nonlinear relationship with a $U$-shaped curve.

Hypothesis 4 (H4b): Block ownership and corporate performance have a nonlinear relationship with an inverted $U$-shaped curve.

\section{Methodology and Data}

\subsection{Empirical Model}

The traditional specification for the economic relation between ownership structure and corporate performance is static without lagged corporate performance. Basically, the nature of the corporate governance-performance 
relationship is dynamic (Wintoki et al., 2012). Therefore, this relationship's static model could not fully reflect the effect of ownership structure on corporate performance, even inducing misleading inferences. The dynamic relationship between ownership structure and corporate performance indicates that the current relationship is driven by the corporate performance's lagged values. In other words, the current corporate performance is determined by both ownership structure and past corporate performance.

To eliminate the channel through which endogeneity biases estimate causal effects due to the potential presence of reverse causality from the dependent variable's impact on explanatory variables, all independent variables are the lagged variables. In other words, we only focus heavily on the influence of explanatory variables on corporate performance but not vice versa (Bellemare et al., 2017).

Hence, we closely follow the theoretical framework and existing empirical evidence in the literature on the relationship between ownership structure and corporate performance such as Liu et al. (2015); Nguyen et al. (2015) as well as the Vietnamese food market characteristics to hypothesize as follows:

$$
\mathrm{CP}_{\mathrm{i}, \mathrm{t}}=\beta_{0}+\beta_{1} \mathrm{CP}_{\mathrm{i}, \mathrm{t}-1}+\sum_{j=1}^{2} \beta_{j} \mathbf{O S} \mathbf{i}_{\mathrm{t}-\mathrm{t}-\mathbf{1}}+\sum_{k=1}^{4} \boldsymbol{\beta}_{k} \mathbf{C V}_{\mathrm{i}, \mathrm{t}-\mathbf{1}}+\mu_{\mathrm{i}}+\Theta_{\mathrm{t}-1}+\mathrm{u}_{\mathrm{i}, \mathrm{t}-1}
$$

The existing empirical studies have documented the non-linear relationship between ownership structure and corporate performance (Cho and Kim, 2007; Chen and $\mathrm{Yu}, 2012)$. Our analysis also introduces the squared ownership structure variables to examine the non-monotonic relationship between ownership structure and corporate performance. The model is as follows:

$$
\begin{aligned}
& \mathrm{CP}_{\mathrm{i}, \mathrm{t}}=\beta_{0}+\beta_{1} \mathrm{CP}_{\mathrm{i}, \mathrm{t}-1}+\sum_{j=1}^{2} \beta_{j} \mathbf{O S}_{\mathrm{i}, \mathrm{t}-\mathbf{1}}+\sum_{j=1}^{2} \beta_{j} \mathbf{O S}_{\mathrm{i}, \mathrm{t}-\mathbf{1}}{ }^{2}+\sum_{k=1}^{4} \beta_{k} \mathrm{CV}_{\mathrm{i}, \mathrm{t}}+\mu_{\mathrm{i}}+ \\
& \Theta_{\mathrm{t}-1}+\mathrm{u}_{\mathrm{i}, \mathrm{t}-1}
\end{aligned}
$$

Where $\mathrm{i}$ index firms and $\mathrm{t}$ indicates the time period. CP is the corporate performance. OS is the ownership structure. $\mu \mathrm{i}$ denotes time-invariant unobservable firm-fixed effects; Ot-1 represents time-fixed effects that are timevariant and common to all companies, ui, $\mathrm{t}-1$ is the time-varying disturbance term.

In Equation (1) and (2), the inclusion of year-fixed effects is to control macroeconomic conditions as they may affect the corporate performance, and we also add firm-fixed effects to allow for the possibility that the corporate performance varies across firms. 


\subsection{Variables Construction}

\subsubsection{Corporate performance measure}

It is unclear which corporate performance measure is the best (Khanna, 2000). Both ROA and ROE are known as accounting-based measures of firm performance and reflect a backward-looking perspective and what the management has accomplished (Demsetz and Villalonga, 2001; Hu and Izumida 2008). Accordingly, ROE is considered the most important ratio for the shareholders because it reflects what shareholders gain per share. In the meanwhile, ROA offers investors profitability information generated from total assets. However, ROA is driven by business cycles and does not tend to differences in systematic risk (Benston, 1985).

Additionally, both ROE and ROA also give investors a fundamental background to make financial decisions by comparing ROEs and ROAs among firms in the same industry. Tobin's Q is a market-based measure from a forward-looking perspective (Demsetz and Villalonga, 2001; Hu and Izumida, 2008) and thus reflects the expected future earnings. However, Tobin's Q is based on problematic assumptions on the illiquidity and untimely disclosure problems; inducing Tobin's Q is not the best measure of corporate performance in most emerging markets. Additionally, the association between ownership structure changes and subsequent corporate performance is driven by discrepancies in corporate performance measures based on accounting and market (Haniffa and Hudaib, 2006).

The existing empirical evidence has used the various measures of corporate performance, including return on equity (ROE) (Demsetz and Lehn, 1985; Demsetz and Villalonga, 2001; Vu et al., 2018); return on assets (ROA) (Li et al., 2007; Hu and Izumida, 2008; Vu et al., 2018) and Tobin's Q (Thomsen and Pedersen, 2000; Gedajlovic and Shapiro, 2002; Kapopoulos and Lazaretou, 2007; Nguyen et al., 2015).

Our analysis only tends to backward-looking profitability. Additionally, to avoid the heterogeneity in the linkage between ownership structure and corporate performance in Haniffa and Hudaib (2006). Therefore, we follow Andres and Vallelado (2008); Vu et al. (2018) and adopt ROA and ROE as the dependent variables to assess Vietnamese food listed firms' corporate performance. The definition of the dependent variables is shown in Table 1.

\subsubsection{Ownership structure measures}

The existing empirical evidence on the nexus ownership structure and corporate performance in developing markets typically tend to state ownership, foreign ownership, managerial ownership, block ownership. Although this industry has gained considerable attention from foreign investors (Phung and Mishra, 2016), 
The Dynamic Relationship between Ownership Structure and Corporate Performance: Evidence from the Vietnamese Food Industry

576

foreign ownership is strictly controlled by policymakers since the food industry is intimately related to food security.

Table 1. Variable definitions

\begin{tabular}{|l|c|l|}
\hline \multicolumn{1}{|c|}{ Variable } & Acronym & \multicolumn{1}{c|}{ Description } \\
\hline $\begin{array}{l}\text { A. Corporate performance } \\
\text { Return on Assets }\end{array}$ & ROA & The ratio of earnings after tax to total assets \\
\hline $\begin{array}{l}\text { Return on Equity } \\
\text { B. Ownership structure }\end{array}$ & ROE & The ratio of earnings after tax to total equity \\
\hline $\begin{array}{l}\text { Managerial ownership } \\
\text { Block ownership }\end{array}$ & MO & $\begin{array}{l}\text { The number of managerial stocks to the } \\
\text { number of stock outstanding }\end{array}$ \\
\hline $\begin{array}{l}\text { Squared managerial } \\
\text { ownership }\end{array}$ & SMO & $\begin{array}{l}\text { The number of stocks held by block-holders } \\
\text { to the number of stock outstanding }\end{array}$ \\
\hline $\begin{array}{l}\text { Squared block } \\
\text { ownership }\end{array}$ & SBO & The square of managerial ownership \\
\hline C. Control variables & SIZE & Total assets \\
\hline Size & LIQ & The current assets to current liabilities \\
\hline Liquidity & LEV & The liabilities to total assets \\
\hline Capital Structure & AGE & The current year minus established year \\
\hline Firm age & & \\
\hline Source: Own study &
\end{tabular}

Source: Own study.

Foreigners have not played an extremely significant role in the proliferation of profitability under Vietnamese policies. Also, the privatization process in Vietnam is successfully conducted to attract more non-state investors by selling their shares to enhance corporate performance. Therefore, the role played by state ownership in improving corporate performance is reduced. To the extent, the privatization process is taken place.

Comprehensively, state ownership disappear. Thus, we do not tend to state ownership to investigate the linkage of ownership structure and corporate performance. In short, we expect the role of managerial shareholdings and block ownership in enhancing corporate performance is more pronounced (Cho and Kim, 2007; Haniffa and Hudaib, 2006; Mandac1 and Gumus, 2010). Therefore, we tend to managerial shareholdings and block ownership to examine the relationship between ownership structure changes and subsequent corporate performance. The definition of the ownership variables is shown in Table 1.

\subsubsection{Control variables}

The absence of control variables is more likely to influence the relationship between ownership structure and corporate performance materially. Therefore, to estimate the net link between ownership structure and corporate performance, we follow the convention in the ownership structure and corporate performance literature (Liu et al., 2015; Liu et al., 2012; Nguyen et al., 2015) and model 
control variables that appear regularly in the literature, including size, liquidity, financial leverage, firm age. The definition of the control variables is shown in Table 1. To solve non-normal residuals, we take the natural logarithm of all variables but not ownership structure due to the convenience of analyzing turning points.

\subsection{Estimation Method}

The relationship between ownership structure and firm performance in the static condition was mainly estimated by the Ordinary Least Square estimator (OLS) (Demsetz and Lehn, 1985; Palia and Lichtenberg, 1999). However, the traditional econometric techniques, such as the OLS or Fixed Effect (FE) estimators, are not appropriate to estimate the effect of ownership structure on firm performance in the dynamic condition since these methods are insufficient to address the potential endogeneity between the lagged dependent variable and the error term, resulting in biases of the estimator for data with large numbers of cross-sections and short time-series and misleading inferences. The SGMM technique combines moment conditions of two simultaneous equations, including both difference and level equations, to overcome important dynamic effects and accounts for endogeneity in the explanatory variables.

Generally, the earlier discussions on econometric techniques for the nexus between ownership structure and firm performance in the dynamic model suggest that the SGMM estimator is the most appropriate method to regress this relationship. Empirically, to deal with inconsistences and misleading inferences in the dynamic model for the nexus between ownership structure and firm performance, Hu and Izumida (2008), Nguyen et al. (2015), and Tran and Le (2020) use the Blundell and Bond (1998) system generalized method of moments (SGMM), estimator. Therefore, we use the SGMM technique in our analysis.

\subsection{Data}

Our database is collected from accounting data related to firm characteristics and provided by Vietstock. Our initial sample includes 55 firms with 660 firm-year observations for food listed firms on both the Hochiminh Stock Exchange and Hanoi Stock Exchange between 2007 and 2018. We only retain firms with no missing data. Besides, due to the presence of de-listed and new listed stocks and the appearance of the lagged variables in the regression specification, for a firm to be included in our analysis using panel data models, we also require the firms to have data for all variables for at least two consecutive years to avoid bias in our regression results. These screening procedures result in a final panel data sample of 43 firms, with 532 firm-year observations. All continuous variables are winsorized at the 1st and 99th percentiles to eliminate the influence of extreme observations. 


\section{Results and Discussions}

\subsection{Descriptive Statistics and Correlations}

Table 2 provides summary statistics for the entire sample. In our sample, an average firm has the natural logarithm of return on total assets and return on equity of -3.035 and -2.307 , respectively. The medians of return on total assets and return on equity are -2.760 and -2.098 , respectively. These results indicate that the standard deviation of return on total assets (1.222) is higher than that of return on equity (1.121). The mean (median) values of the managerial ownership and block ownership are $10.5 \%(3 \%)$ and $52.2 \%(51.1 \%)$, respectively. This implies that the block ownership of Vietnamese listed food firms is relatively high. The standard deviation of managerial shareholdings $(0.3)$ is higher than that of block ownership ratios (0.216). For liquidity measure, our sample firms have an average and median of liquidity of -2.870 and -2.996 . Next, the leverage has its mean (median) at $-0.850(-0.723)$, with a standard deviation of 0.537 . The median (27.455) and mean (27.615) of size are quite similar, respectively. Finally, the natural logarithm of age has a mean value of 2.903 and a median value of 2.917 .

Table 2. Descriptive statistics

\begin{tabular}{|c|c|c|c|c|c|c|c|c|}
\hline Variables & N & Mean & Median & Std. Dev. & P10 & P25 & P75 & P90 \\
\hline ROA & 489 & -3.035 & -2.760 & 1.222 & -4.768 & -3.510 & -2.233 & -1.735 \\
\hline ROE & 489 & -2.307 & -2.098 & 1.121 & -3.592 & -2.694 & -1.548 & -1.215 \\
\hline MO & 387 & 0.105 & 0.030 & 0.150 & 0.001 & 0.007 & 0.154 & 0.341 \\
\hline BO & 423 & 0.522 & 0.511 & 0.216 & 0.253 & 0.362 & 0.673 & 0.836 \\
\hline LIQ & 515 & -2.996 & -2.870 & 1.352 & -4.810 & -3.711 & -1.906 & -1.462 \\
\hline LEV & 515 & -0.850 & -0.723 & 0.537 & -1.563 & -1.129 & -0.446 & -0.285 \\
\hline SIZE & 515 & 27.615 & 27.454 & 1.552 & 25.696 & 26.385 & 28.559 & 29.831 \\
\hline AGE & 532 & 2.903 & 2.917 & 0.763 & 1.946 & 2.485 & 3.434 & 3.761 \\
\hline
\end{tabular}

Source: Own study.

Table 3 illustrates the correlation matrix of both the dependent and independent variables. An important hypothesis is no multicollinearity among the explanatory variables. All of the correlation coefficients in Table A3 are less than 0.93. Following Klein's rule of thumb (Klein, 1962), it can be concluded that the independent variables in our equations are not multi-collinear ${ }^{6}$.

${ }^{6}$ The inferences of VIF and Pearson correlation are based on the rule of thumb. Therefore, only one is sufficient to test multicollinearity. Hence, to conserve space, these VIF indexes are unreported. 
Table 3. Pairwise correlations

\begin{tabular}{|c|c|c|c|c|c|c|c|c|}
\hline Variables & ROE & ROA & MO & BO & LIQ & LEV & SIZE & AGE \\
\hline ROE & 1.000 & & & & & & & \\
\hline ROA & $0.932^{*}$ & 1.000 & & & & & & \\
\hline MO & $-0.201^{*}$ & $-0.155^{*}$ & 1.000 & & & & & \\
\hline BO & $0.190^{*}$ & $0.186^{*}$ & 0.063 & 1.000 & & & & \\
\hline LIQ & $0.341^{*}$ & $0.237^{*}$ & $-0.278^{*}$ & $0.171^{*}$ & 1.000 & & & \\
\hline LEV & $-0.279^{*}$ & 0.034 & $0.182^{*}$ & $0.094^{*}$ & $-0.280^{*}$ & 1.000 & & \\
\hline SIZE & 0.049 & 0.044 & $0.171^{*}$ & $0.254^{*}$ & 0.057 & $0.082^{*}$ & 1.000 & \\
\hline AGE & $0.166^{*}$ & $0.087^{*}$ & $-0.214^{*}$ & $0.276^{*}$ & $0.257^{*}$ & $-0.133^{*}$ & $0.159^{*}$ & 1.000 \\
\hline
\end{tabular}

Note: * shows significance at the 0.1 level

Source: Own study.

\subsection{Results and Discussions}

\subsubsection{Reliability tests}

Table 4 reports the linear and non-linear models' reliability tests in Panels A and $\mathrm{B}$, respectively. The reliability tests in Panel A and B show that our models are satisfactory to investigate the relationship between ownership structure and corporate performance.

The Hansen and AR (2) second-order serial correlation tests indicate the overall model fit. Specifically, the Hansen test results of over-identifying restrictions document a high P-value, which is over 0.05 , indicating the instruments' validity in the SGMM estimator. The P-values of AR (1) and AR (2) are less and over 0.05 , respectively, implying that the hypothesis of no second-order autocorrelation of the disturbance term is not rejected at the 5\% significance level.

This indicates the absence of second-order correlation in differences and that of first-order correlation in levels. The Wald test result is significant at the $1 \%$ level, implying that the significance of the right-hand side variables or our model is correctly specified. Overall, the reliability tests indicate that the GMM estimator is appropriate to analyze our results.

\subsubsection{Linear regression results}

Table 5 reports the nexus's main regression results between ownership structure and corporate performance using the two-step SGMM technique for Equation (1). Our independent variables of interest are managerial holdings and block ownership. We show the regression results for managerial shareholdings' impact on firm performance in Model (1) and (2). We report the regression results for ROA and ROE as the dependent variables in Model (1) and (2), respectively. 
The Dynamic Relationship between Ownership Structure and Corporate Performance: 580 Evidence from the Vietnamese Food Industry

Table 4. Reliability tests

Panel A: Linear specification

\begin{tabular}{|c|c|c|c|c|}
\hline \multirow[t]{3}{*}{ Variables } & \multicolumn{2}{|c|}{ MO } & \multicolumn{2}{|c|}{ BO } \\
\hline & \multicolumn{4}{|c|}{ Model } \\
\hline & (1) & (2) & (3) & (4) \\
\hline Number of firms & 40 & 40 & 39 & 39 \\
\hline Hansen test & 0.983 & 0.982 & 0.944 & 0.886 \\
\hline AR1 & 0.000 & 0.000 & 0.000 & 0.000 \\
\hline AR2 & 0.297 & 0.336 & 0.876 & 0.796 \\
\hline Wald test & 0.000 & 0.000 & 0.000 & 0.000 \\
\hline \multicolumn{5}{|c|}{ Panel B: Non-linear specification } \\
\hline \multirow[t]{3}{*}{ Variables } & \multicolumn{2}{|c|}{ MO } & \multicolumn{2}{|c|}{ BO } \\
\hline & \multicolumn{4}{|c|}{ Model } \\
\hline & (1) & (2) & (3) & (4) \\
\hline Number of firms & 40 & 40 & 39 & 39 \\
\hline Hansen test & 0.887 & 0.980 & 0.992 & 0.979 \\
\hline AR1 & 0.000 & 0.040 & 0.000 & 0.000 \\
\hline AR2 & 0.397 & 0.440 & 0.672 & 0.651 \\
\hline Wald test & 0.000 & 0.000 & 0.000 & 0.000 \\
\hline
\end{tabular}

Source: Own study.

Table 5. Linear regression results

\begin{tabular}{|c|c|c|c|c|}
\hline \multirow[t]{3}{*}{ Variables } & \multicolumn{2}{|c|}{ MO } & \multicolumn{2}{|c|}{ BO } \\
\hline & \multicolumn{4}{|c|}{ Model } \\
\hline & (1) & (2) & (3) & (4) \\
\hline \multirow[t]{2}{*}{ ROA } & $0.585 * * *$ & & $0.452 * * *$ & \\
\hline & $(0.020)$ & & $(0.035)$ & \\
\hline \multirow[t]{2}{*}{ ROE } & & $0.583 * * *$ & & $0.407 * * *$ \\
\hline & & $(0.020)$ & & $(0.025)$ \\
\hline \multirow[t]{2}{*}{ MO } & $-0.673 * * *$ & $-1.069 * * *$ & & \\
\hline & $(0.156)$ & $(0.190)$ & & \\
\hline \multirow[t]{2}{*}{ BO } & & & $-0.458 * *$ & $-0.569 * * *$ \\
\hline & & & $(0.191)$ & $(0.176)$ \\
\hline \multirow[t]{2}{*}{ LIQ } & $0.052 * * *$ & $0.018 *$ & $0.091 * * *$ & $0.058 * * *$ \\
\hline & $(0.013)$ & $(0.010)$ & $(0.015)$ & $(0.015)$ \\
\hline \multirow[t]{2}{*}{ LEV } & $-0.250 * * *$ & $-0.110 * *$ & $-0.306 * * *$ & $-0.164 * * *$ \\
\hline & $(0.040)$ & $(0.046)$ & $(0.038)$ & $(0.049)$ \\
\hline \multirow[t]{2}{*}{ SIZE } & 0.001 & -0.012 & -0.004 & 0.009 \\
\hline & $(0.021)$ & $(0.021)$ & $(0.026)$ & $(0.023)$ \\
\hline \multirow[t]{2}{*}{ AGE } & $0.107 * * *$ & 0.027 & $0.159 * * *$ & $0.154 * * *$ \\
\hline & $(0.028)$ & $(0.025)$ & $(0.059)$ & $(0.024)$ \\
\hline \multirow[t]{2}{*}{ Constant } & $-1.610 * *$ & -0.610 & $-1.821 * *$ & $-1.791 * * *$ \\
\hline & $(0.662)$ & $(0.640)$ & $(0.818)$ & $(0.663)$ \\
\hline Fixed effects & FY & FY & FY & FY \\
\hline Observations & 337 & 337 & 379 & 379 \\
\hline
\end{tabular}

Note: ***,**, and $*$ indicate significance at the 1\%, 5\%, and $10 \%$ levels, respectively.

Standard errors are reported in parentheses.

Source: Own study.

We find that the coefficients on managerial ownership in Model (1) are negative and highly significant at a $1 \%$ level. Similarly, the coefficient on managerial 
ownership remains significantly negative in Model (2). Taken together, we conclude that managerial ownership has a negative influence on corporate performance at the $1 \%$ significance level. Overall, our new findings are consistent with theoretical prediction and existing empirical evidence around the world on the effect of managerial shareholdings on corporate performance. Specifically, the results are in contrast to H1a but lend strong support to hypothesis H1b. Accordingly, the negative relationship between managerial ownership changes and subsequent corporate performance is in line with the argument related to the entrenchment hypothesis that firms do not benefit from managerial ownership (Palia and Lichtenberg, 1999). Our empirical evidence is consistent with Cui and Mak (2002), Haniffa and Hudaib (2006), Irina and Nadezhda (2009), Liang et al. (2011), and Mandac1 and Gumus (2010) but is not in line with Kim et al. (2004), Sheu and Yang (2005), Kapopoulos and Lazaretou (2007), and Li et al. (2007). Our empirical evidence is in contrast with Hoang et al. (2017).

Clearly, both managerial ownership and corporate performance in the manufacturing industry are markedly different from those in the food industry, inducing discrepancies in the linkage between managerial ownership and firm performance among industries. Additionally, Hoang et al. (2017) only use corporate performance measures based on the forward-looking perspective. In the meanwhile, our analysis only tends to backward-looking performance. Therefore, the heterogeneity in the linkage between managerial ownership and corporate performance might be attributable to measures, as indicated in Haniffa and Hudaib (2006).

In terms of block ownership, we show the regression results for the impact of block ownership on firm performance in Model (3) and (4). We find that the coefficient on block ownership is negative and highly significant at $1 \%$ for ROA as the dependent variable in Model (3). Furthermore, the coefficient on block ownership in Model (4) remains unchanged in ROE's case served as the dependent variable. Therefore, our empirical analysis indicates that corporate performance is a negative function of block ownership. Overall, the new findings are consistent with both the theoretical prediction and the existing empirical evidence around the world on the ownership structure's effect on corporate performance. Specifically, the results support hypothesis H2b that block ownership is negatively associated with firm performance. Furthermore, the negative relationship between changes in block ownership and subsequent corporate performance is in line with our prediction that block-holders cause a negative entrenchment effect on corporate performance since they accumulate private benefits of control through pyramid business structures and crossholdings across different firms (Claessens et al., 2000). Our empirical evidence is consistent with Lefort and Urzúa (2008), Ducassy and Montandrau (2015) but in contrast to Cho and Kim (2007), Kapopoulos and Lazaretou (2007). 
In Vietnam, Hoang et al. (2017), and Tran and Le (2020) find no statistical significance of a relationship between block ownership and corporate performance for Vietnamese manufacturing listed firms and Vietnamese listed firms, respectively. Therefore, the combination of Hoang et al. (2017), Tran and Le (2020), and our analysis indicates that the absence of a linear relationship between block ownership and corporate performance could be overwhelmingly dominated by other industries rather than the food industry. In other words, the differences in the linkage between block ownership and firm performance seem to be attributable to discrepancies among industries. As discussed above, the heterogeneity in the linkage between block ownership and corporate performance might be attributable to measures.

When we use both ROA and ROE as the dependent variables, we always find managerial shareholdings and ownership concentration to be significantly and negatively associated with corporate performance for Vietnamese food listed firms despite the difference in the institutional environment, macroeconomic conditions.

\subsubsection{Non-linear regression results}

In Table 6, we provide the non-linear regression results for the effect of managerial ownership on firm performance using the two-step SGMM technique for Equation (2) in Model (1) and (2), while Models (3) and (4) report the nonlinear relationship between block ownership and corporate performance. Our independent variables of interest are the square of managerial ownership and block ownership.

Our findings from Model (1) and (2) show that the coefficients on the square of managerial ownership are positive and significant at a $1 \%$ level for both ROA and ROE served as the dependent variables, respectively, indicating the existence of a nonlinear relationship between managerial ownership and firm performance. Accordingly, this correlation is described as the U-shaped pattern, which is in line with H3a. This nonlinear relationship is consistent with the prediction related to both the incentive hypothesis and the entrenchment hypothesis that a nexus between managerial ownership and corporate performance appears negative and positive in the first place and second place, respectively. Our new findings related to the nonlinear relationship between managerial ownership and corporate performance are almost a mirror image of Mueller and Spitz-Oener (2006) and Chen and $\mathrm{Yu}$ (2012). However, our findings are in line with Cui and Mak (2002) and Khan et al. (2014), who reveal the nonlinear relationship between managerial ownership and firm performance with a U-shaped curve for high R \& D firms in the USA and Australia. Our empirical evidence conflicts with Hoang et al. (2017). 
Table 6. Non-linear regression results

\begin{tabular}{|c|c|c|c|c|}
\hline \multirow[t]{3}{*}{ Variables } & \multicolumn{2}{|c|}{ MO } & \multicolumn{2}{|c|}{ BO } \\
\hline & \multicolumn{4}{|c|}{ Model } \\
\hline & (1) & (2) & (3) & (4) \\
\hline ROA & $0.561 * * *$ & & $0.614 * * *$ & \\
\hline & $(0.029)$ & & $(0.026)$ & \\
\hline ROE & & $0.533 * * *$ & & $0.542 * * *$ \\
\hline & & $(0.021)$ & & $(0.032)$ \\
\hline MO & $-3.480 * * *$ & $-2.624 * * *$ & & \\
\hline & $(0.556)$ & $(0.389)$ & & \\
\hline SMO & $3.355 * * *$ & $2.113 * * *$ & & \\
\hline & $(0.478)$ & $(0.317)$ & & \\
\hline BO & & & $-7.294 * * *$ & $-5.567 * * *$ \\
\hline & & & $(0.816)$ & $(0.531)$ \\
\hline SBO & & & $6.859 * * *$ & $6.011 * * *$ \\
\hline & & & $(0.599)$ & $(0.500)$ \\
\hline LIQ & $0.055 * * *$ & $0.043 * * *$ & 0.019 & 0.025 \\
\hline & $(0.014)$ & $(0.009)$ & (0.020) & $(0.016)$ \\
\hline LEV & $-0.310 * * *$ & $-0.123^{*}$ & $-0.217 * * *$ & $-0.104 *$ \\
\hline & $(0.036)$ & (0.069) & $(0.055)$ & $(0.057)$ \\
\hline SIZE & -0.022 & -0.022 & -0.019 & -0.071 \\
\hline & $(0.022)$ & (0.019) & $(0.029)$ & $(0.058)$ \\
\hline AGE & $0.112 * *$ & 0.034 & 0.029 & -0.042 \\
\hline & $(0.046)$ & (0.048) & $(0.040)$ & (0.055) \\
\hline Constant & -0.960 & -0.381 & 0.701 & 1.980 \\
\hline & $(0.743)$ & $(0.655)$ & $(0.846)$ & (1.608) \\
\hline Fixed effects & FY & FY & FY & FY \\
\hline Observations & 337 & 337 & 379 & 379 \\
\hline
\end{tabular}

Note: $* * *, * *$, and $*$ indicate significance at the $1 \%, 5 \%$, and $10 \%$ levels, respectively.

Standard errors are reported in parentheses.

Source: Own study.

A possible explanation for the heterogeneity is that the differences in both managerial ownership and corporate performance among industries and measures inducing discrepancies on the existence of the non-monotonic relationship of managerial ownership and firm performance among industries. We also find that the nonlinear relationship between managerial ownership and corporate performance is with the turning point at approximately $51.86 \%$ and $62.09 \%$ for the dependent variables of ROA and ROE, respectively. This threshold is higher than the findings found in under-developed markets.

The results, reported in Models (3) and (4), show that the coefficients on the square of block ownership are positive and significant at $1 \%$ level for both ROA and ROE as the dependent variables, indicating the existence of the nonlinear relationship between block ownership and corporate performance. Therefore, our evidence lends strong support to the central hypothesis (H4a) that block ownership and firm performance have a nonlinear relationship with a U-shaped pattern. Our new findings are almost a mirror image of those in Balsmeier and Czarnitzki (2017) but are in line with Cho and Kim (2007). We also show that 
the maximum points of the hump-shaped relationship between block ownership and corporate performance are $53.17 \%$ and $46.31 \%$ for ROA and ROE's dependent variables, respectively. This threshold is higher than the findings found in under-developed markets. Furthermore, the coefficients on both managerial shareholdings and block ownership are qualitatively similar to the baseline findings. In Vietnam, the non-existence of a quadratic relation between ownership concentration and corporate performance is well documented (Liu et al., 2012; Hoang et al., 2017). Meanwhile, our findings indicate the nonmonotonic relationship between ownership concentration and corporate performance for Vietnamese food listed firms. This implies that the empirical evidence on the quadratic relation between ownership concentration and firm profitability in Vietnam is mixed, conditional on industries and measures.

When we use both ROA and ROE as the dependent variables, we always find that the U-shaped relationship between ownership structure and corporate performance exists for Vietnamese food listed firms despite the difference in the institutional environment, macroeconomic conditions.

The Vietnamese financial market is known as the young market. Hence, the market variation is large, mainly conditional on international financial markets and macroeconomic conditions. Consequently, the agency problem and asymmetric information become more pronounced in Vietnam compared to the developed countries in general (Nguyen and Ramachandran, 2006; Huynh et al., 2020) and in the food industry in particular. Additionally, similar to most emerging markets, corporate governance is characterized by high capital concentration, limited information, and weak disclosures in policies to protect minority shareholders (Phung and Mishra, 2016). Furthermore, most Vietnamese food listed firms are derived from state firms where the managers have played a vital role in making decisions. Although the privatization process can separate ownership and control, the self-interest behaviors stemming from "the state culture" are intimately related to inertia. State ownership accounts for a high level (Phung and Mishra, 2016) that the state representatives in firms are typically block-holders and managers.

Therefore, both block-holders and managers take advantage of available resources to accumulate private benefits rather than value-maximization if they hold shares with a certain threshold. The opaque information environment in Vietnam allows them to seize private benefits without being detected. To the extent that the conflicts of interest between controlling shareholders and minority shareholders are severe and the transparency related to the mitigation of information asymmetry is higher, their self-interest behaviors are more likely to be detected and legally riskier since minority shareholders have incentives to collect information for the protection of shareholder rights. Both block-holders and managers are not motivated to indulge in non-value maximizing behaviors and tend to synchronize shareholders' and managers' interests. Hence, both 
managerial shareholdings and block ownership can lower agency costs and strengthen asset utilization efficiency. Furthermore, block ownership is higher than managerial ownership. Therefore, the role played by block ownership is more important compared to managerial ownership in making decisions on corporate performance. Consequently, in an opaque information environment like Vietnam, block-holders accumulate private control benefits through pyramid business structures and cross-holdings across different firms.

However, the higher fraction of the shareholders' being held mitigates the conflicts of interest between managers and shareholders through shareholders' more strong rights to the extent of the high concentrated ownership level. Therefore, block-holders with enough voting control are encouraged to acquire more private information and monitor better managers' discipline and punish for managers' non-value maximizing behaviors through a proxy fight or a takeover.

\section{Conclusion}

Our analysis examines the dynamic relationship between ownership structure and corporate performance in the context of an emerging market. Our sample includes 43 firms in the food industry listed on both the Hochiminh Stock Exchange and Hanoi Stock Exchange during 2007-2018 with 532 firm-year observations. We use the SGMM technique to indicate that managerial shareholdings and ownership concentration negatively drive corporate performance. We further find that corporate performance is also a positive function of both managerial shareholdings and ownership concentration.

The results support the entrenchment hypothesis that the divergence of ownership and control helps managers accumulate substantial private benefits without actually bearing the costs. Block-holders also accumulate private benefits of control through pyramid business structures and cross-holdings across different firms. Therefore, both block-holders and managers are motivated to indulge in non-value maximizing behavior, deteriorating corporate performance. However, the entrenchment hypothesis does only exist at a low level of ownership. At the high level of ownership, the entrenchment hypothesis is positioned by the incentive hypothesis. Accordingly, their self-interest behaviors are more likely to be detected and legally riskier. They are motivated to indulge in valuemaximizing behaviors and synchronize the interests of shareholders and managers. Thus, both managerial shareholdings and block ownership can lower agency costs and strengthen asset utilization efficiency.

\section{References:}

Andres P., Vallelado E. 2008. Corporate governance in banking: the role of board of directors. Journal of Banking and Finance, Vol. 32, No. 12, 2570-2580. 
Balsmeier, B., Czarnitzki, D. 2017. Ownership concentration, institutional development and firm performance in Central and Eastern Europe. Managerial and Decision Economics, 38(2), 178-192.

Bellemare, M.F., Masaki, T., Pepinsky, T.B. 2017. Lagged explanatory variables and the estimation of causal effect. The Journal of Politics, 79(3), 949-963.

Benston, G.J. 1985. The validity of profits-structure studies with particular reference to the FTC's line of business data. The American Economic Review, 75(1), 37-67.

Blundell, R., Bond, S. 1998. Initial conditions and moment restrictions in dynamic panel data models. Journal of Econometrics, 87(1), 115-143.

Chen, C.J., Yu, C.M.J. 2012. Managerial ownership, diversification, and firm performance: Evidence from an emerging market. International Business Review, 21(3), 518-534.

Cho, D.S., Kim, J. 2007. Outside directors, ownership structure and firm profitability in Korea. Corporate Governance: An International Review, 15(2), 239-250.

Claessens, S., Djankov, S., Lang, L.H. P. 2000. The separation of ownership and control in East Asian Corporations. Journal of Financial Economics, 58(1), 81-112.

Crutchley, C.E., Hansen, R.S. 1989. A test of the agency theory of managerial ownership, corporate leverage, and corporate dividends. Financial Management, 36-46.

Cui, H., Mak, Y.T. 2002. The relationship between managerial ownership and firm performance in high RandD firms. Journal of Corporate Finance, 8(4), 313-336.

Demsetz, H., Lehn, K. 1985. The structure of corporate ownership: Causes and consequences. Journal of political economy, 93(6), 1155-1177.

Demsetz, H., Villalonga, B. 2001. Ownership structure and corporate performance. Journal of corporate finance, 7(3), 209-233.

Ducassy, I., Montandrau, S. 2015. Corporate social performance, ownership structure, and corporate governance in France. Research in International Business and Finance, 34, 383-396.

Earle, J.S., Kucsera, C., Telegdy, Á. 2005. Ownership concentration and corporate performance on the Budapest stock exchange: Do too many cooks spoil the goulash? Corporate Governance: An International Review, 13(2), 254-264.

Fan, J.P.H., Wei, K.C.J., Xu, X. 2011. Corporate finance and governance in emerging markets: A selective review and an agenda for future research. Journal of Corporate Finance, 17(2), 207-214.

Filatotchev, I., Jackson, G., Nakajima, C. 2013. Corporate governance and national institutions: A review and emerging research agenda. Asia Pacific Journal of Management, 30(4), 965-986.

Gedajlovic, E., Shapiro, D.M. 2002. Ownership structure and firm profitability in Japan. Academy of management journal, 45(3), 565-575.

Grosfeld, I., Hashi, I. 2007. Changes in ownership concentration in mass privatised firms: Evidence from Poland and the Czech Republic. Corporate Governance: An International Review, 15(4), 520-534.

Haniffa, R., Hudaib, M. 2006. Corporate governance structure and performance of Malaysian listed companies. Journal of Business Finance and Accounting, 33(7-8), 1034-1062.

Hoang, L.T., Nguyen, C.C., Hu, B. 2017. Ownership structure and firm performance improvement: Does it matter in the vietnamese stock market? Economic Papers: A journal of applied economics and policy, 36(4), 416-428. 
Hu, Y., Izumida, S. 2008. Ownership concentration and corporate performance: A causal analysis with Japanese panel data. Corporate Governance: An International Review, 16(4), 342-358.

Huynh, T.L.D., Wu, J., Duong, A.T. 2020. Information Asymmetry and firm value: Is Vietnam different? The Journal of Economic Asymmetries, 21, e00147.

Irina, I., Nadezhda, Z. 2009. The relationship between corporate governance and company performance in concentrated ownership systems: The case of Germany. Journal of corporate finance, 4(12), 34-56.

Jensen, M.C. 1986. Agency costs of free cash flow, corporate finance, and takeovers. The American Economic Review, 76(2), 323-329.

Jensen, M.C., Meckling, W.H. 1976. Theory of the firm: Managerial behavior, agency costs and ownership structure. Journal of Financial Economics, 3(4), 305-360.

Kang, J.K.,Shivdasani, A. 1995. Firm performance, corporate governance, and top executive turnover in Japan. Journal of financial Economics, 38(1), 29-58.

Kaplan, S.N., Minton, B.A. 1994. Appointments of outsiders to Japanese boards: Determinants and implications for managers. Journal of Financial Economics, 36(2), 225-258.

Kapopoulos, P., Lazaretou, S. 2007. Corporate ownership structure and firm performance: evidence from Greek firms. Corporate Governance: An International Review, 15(2), 144-158.

Khan, A., Mather, P., Balachandran, B. 2014. Managerial share ownership and operating performance: do independent and executive directors have different incentives? Australian Journal of Management, 39(1), 47-71.

Khanna, T. 2000. Business groups and social welfare in emerging markets: Existing evidence and unanswered questions. European Economic Review, 44(4-6), 748761.

Kim, K.A., Kitsabunnarat, P., Nofsinger, J.R. 2004. Ownership and operating performance in an emerging market: evidence from Thai IPO firms. Journal of Corporate Finance, 10(3), 355-381. doi:https://doi.org/10.1016/S09291199(02)00019-6.

Klein, L.R. 1962. An introduction to econometrics. Prentice-Hall, New Jersey, 62-64.

Lefort, F., Urzúa, F. 2008. Board independence, firm performance and ownership concentration: Evidence from Chile. Journal of business research, 61(6), 615622.

Li, D., Moshirian, F., Nguyen, P., Tan, L.W. 2007. Managerial ownership and firm performance: Evidence from China's privatizations. Research in International Business and Finance, 21(3), 396-413.

Liang, C.J., Lin, Y.L., Huang, T.T. 2011. Does endogenously determined ownership matter on performance? Dynamic evidence from the emerging Taiwan market. Emerging Markets Finance and Trade, 47(6), 120-133.

Liu, C., Uchida, K., Yang, Y. 2012. Corporate governance and firm value during the global financial crisis: Evidence from China. International Review of Financial Analysis, 21, 70-80.

Mandac1, P., Gumus, G. 2010. Ownership concentration, managerial ownership and firm performance: Evidence from Turkey. South East European Journal of Economics and Business, 5(1), 57-66.

Margaritis, D., Psillaki, M. 2010. Capital structure, equity ownership and firm performance. Journal of banking and finance, 34(3), 621-632. 
Morck, R., Shleifer, A., Vishny, R.W. 1988. Management ownership and market valuation: An empirical analysis. Journal of Financial Economics, 20, 293-315.

Mueller, E., Spitz-Oener, A. 2006. Managerial ownership and company performance in German small and medium-sized private enterprises. German Economic Review, 7(2), 233-247.

Nguyen, Ramachandran. 2006. Capital structure in small and medium-sized enterprises: the case of Vietnam. ASEAN Economic bulletin, 23(2), 192-211.

Nguyen, T., Locke, S., Reddy, K. 2015. Ownership concentration and corporate performance from a dynamic perspective: Does national governance quality matter? International Review of Financial Analysis, 41, 148-161.

Palia, D., Lichtenberg, F. 199. Managerial ownership and firm performance: A reexamination using productivity measurement. Journal of corporate finance, 5(4), 323-339.

Phung, D.N., Mishra, A.V. 2016. Ownership structure and firm performance: Evidence from Vietnamese listed firms. Australian Economic Papers, 55(1), 63-98.

Sheu, H.J., Yang, C.Y. 2005. Insider Ownership Structure and Firm Performance: a productivity perspective study in Taiwan's electronics industry. Corporate Governance: An International Review, 13(2), 326-337.

Shivdasani, A. 1993. Board composition, ownership structure, and hostile takeovers. Journal of Accounting and Economics, 16(1), 167-198.

Shleifer, A., Vishny, R.W. 1986. Large shareholders and corporate control. Journal of political economy, 94(3 Part 1), 461-488.

Shleifer, A., Vishny, R.W. 1999. A survey of corporate governance. The Journal of Finance, 52(2), 737-783.

Thomsen, S., Pedersen, T. 2000. Ownership structure and economic performance in the largest European companies. Strategic Management Journal, 21(6), 689-705.

Tran, N.H., Le, C.D. 2020. Ownership concentration, corporate risk-taking and performance: Evidence from Vietnamese listed firms. Cogent Economics and Finance, 8(1), 1732640.

Vu, M.C., Phan, T.T., Le, N.T. 2018. Relationship between board ownership structure and firm financial performance in transitional economy: The case of Vietnam. Research in International Business and Finance, 45, 512-528.

Welch, E. 2003. The relationship between ownership structure and performance in listed Australian companies. Australian Journal of Management, 28(3), 287-305.

Wintoki, M.B., Linck, J.S., Netter, J.M. 2012. Endogeneity and the dynamics of internal corporate governance. Journal of Financial Economics, 105(3), 581-606. 